\title{
Ophiocordyceps pulvinata Induces Caspase-Dependent Apoptosis through Mitochondrial Impairment in Human Leukemia Cells
}

\author{
Yukiko Ogawa $^{1 *}$, Osamu Morinaga ${ }^{2}$, Nobuo Yahagi $^{3}$, \\ Remiko Yahagi $^{3}$ and Hidemitsu Kobayashi ${ }^{4}$
}

\author{
${ }^{1}$ Divisions of Infection Control and Prevention, Department of Pharmacy, Faculty of \\ Pharmaceutical Science, Nagasaki International University, 2825-7 Huis Ten Bosch, Sasebo, \\ Nagasaki 859-3298, Japan \\ ${ }^{2}$ Department of Natural Medicines, Daiichi University of Pharmacy, 22-1 Tamagawa-cho, \\ Minami-ku, Fukuoka, 815-8511, Japan \\ ${ }^{3}$ Natural Medical Plant and Microbiological Organism Research, Mamurogawa-machi, Mogami- \\ gun, Yamagata, 999-5604, Japan \\ ${ }^{4}$ Divisions of Microbiology, Department of Pharmacy, Faculty of Pharmaceutical Science, \\ Nagasaki International University, 2825-7 Huis Ten Bosch, Sasebo, Nagasaki 859-3298, Japan \\ *Corresponding author
}

\section{A B S T R A C T}

\section{Keywords}

Ophiocordyceps pulvinata, antitumor activity, apoptosis, medicinal plants, leukemia cells.

Article Info

Accepted:

29 December 2016

Available Online:

10 January 2017
Cordyceps is a genus of fungi from the Cordycipitaceae family that grows using host insects as the nutritional source. This genus comprises approximately 500 species worldwide. In the present study, culturing 16 species from 3 genuses of Chu-Soh, namely, Cordyceps, Ophiocordyceps, and Isaria, were successfully artificially cultured We then specifically investigated the antitumor effects of Ophiocordyceps pulvinata on human cancer cells. Secondary metabolites of $O$. pulvinata (OP-FD) showed a significant antiproliferative effect on breast cancer and leukemia cells at low concentrations but not on gastric and pancreatic cancer cells at the same concentrations. Virtually no effect was observed in normal human dermal fibroblasts (NHDF) cells. As OP-FD did not lose antitumor activity on heating, further fractionation with organic solvents was conducted to investigate the antitumor effects. The hexane $(\mathrm{OP}-\mathrm{He})$ and chloroform $(\mathrm{OP}-\mathrm{CH})$ fractions showed a potent cytotoxic effect on human breast cancer and leukemia cells at lower concentrations than OP-FD. Furthermore, OP-He-induced cell death was characterized by mitochondrial impairment, loss of mitochondrial membrane potential $\left(\Delta \Psi_{\mathrm{m}}\right)$, caspase-9 and-3 activation, sub- $\mathrm{G}_{1}$ phase DNA, chromatin condensation, and DNA fragmentation. These results indicate that the cytotoxicity of $O$. pulvinata to leukemia cells is due to apoptosis via the caspase-dependent mitochondrial pathway.

\section{Introduction}

In Japan, more than 40,000 women are diagnosed with breast cancer and more than 10,000 women die of breast cancer each year. Compared to its incidence 30 years ago, the incidence of breast cancer has increased nearly 4-fold and mortality from breast cancer has increased nearly 3-fold. Breast cancer accounts for approximately half of all 
metastatic bone tumors. Furthermore, patients with early-stage breast cancer are at an increased risk of developing leukemia after receiving chemotherapy and radiotherapy (Saito et al., 2009; Sagara et al., 2016).

Cordyceps, known as the Kampo formulation of "Chu-So," refers to fungi (mushrooms) that parasitize living insects and form hostspecific fruiting bodies after the insects die (Paterson et al., 2008). In taxonomy, the genus Cordyceps is part of the Clavicipitaceae family from the order Hypocreales of the division Ascomycota. Cordyceps fungi parasitize various different insects depending on the species, and more than 360 species are found within Japan (Takano et al., 1996; Yahagi et al., 1999). Cordyceps has been acknowledged as an important pharmaceutical resource in recent years. However, it has long been used as a natural medicine and medicinal resource (Bok et al., 1999, Cheng et al., 2013; Nakamura et al., 1999; Oh et al., 2008; Shao et al., 2016; $\mathrm{Yu}$ et al., 2016). The quantities required to utilize Cordyceps as a medicinal resource are difficult to obtain because certain species are rare, while others lack complete information on drug efficacy and active ingredients. Despite the empirically well-known medicinal effects of Cordyceps, research on its physiological activities has been hampered due to its extremely small supply available from the natural environment (Kodama et al., 2000; Lee et al., 2013; Lee et al., 2016; Ma et al., 2015).

With artificial culturing methods involving insects (Sato et al., 2002), the effects of insect components on safety in medicinal and food applications cannot be ruled out, and medicinal effects may vary between different lots. Thus, we established a culture system without the use of insects. We previously screened 16 artificially cultivated Cordyceps preparations to study the growth inhibitory effects on human cancer cells. Each Cordyceps preparation showed a distinct pattern of cell specificity (Yahagi et al., 1999; Yahagi et al., 2004; Ogawa et al., 2014).

Ophiocordyceps pulvinata, the Cordyceps species in the present study, was originally discovered by Mr. Yoshitaka Kaitsu in Iidate Village in Fukushima Prefecture in 1986. O. pulvinata is an ascomycete in the genus Cordyceps that parasitizes ants from the family Formicidae in the order Hymenoptera. O. pulvinata generates a Torrubiella-type fruiting part between the head and chest nodule in a scarf-like manner; however, no details on the physiological activities of components from this mushroom are known. In the present study, we assessed the mechanism of breast cancer and leukemia cell death activity (in vitro) of secondary metabolites from artificially cultured $O$. pulvinata. The aim of our work was to decrease the side effects of chemotherapy and the risk of developing leukemia due to radiation therapy in patients with breast cancer.

\section{Materials and Methods}

\section{Materials}

\section{Cordyceps species Fungal Mycelial Cultibation}

Parasitic mushroom, Chu-Soh, Ophiocordyceps pulvinata sp.nov were harvested from infected insects at Iidate Village (Fukushima Prefecture, Japan) between 2000-2007. The ascospores isolated from perithecium of $O$. pulvinata were inoculated into an autoclaved culture medium composed of $0.3 \%$ yeast extract, $0.5 \%$ glucose and $0.016 \%$ inosine in a 200 ml-flask, and left in the dark for 14 month at $18{ }^{\circ} \mathrm{C}$ (Yahagi et al., 1999). Conidispores were growing from developing colonies of the new 
hyphae in the artificial medium 6 month after inoculaton. The hyphae of Cordyceps species were carefully removed from the medium by filtration, and the filtrate was centrifuged at $10,000 \mathrm{rpm}$ for 60 minutes. The supernatant was lyophilized to give dark-brownish powder (OP-FD). OP-FD were extracted with methanol. The $\mathrm{MeOH}$ extract was suspended in water, and then partitioned with Hexan $(\mathrm{OP}-\mathrm{He}), \mathrm{CHCl}_{3}(\mathrm{OP}-\mathrm{CH}), \mathrm{EtOAc}(\mathrm{OP}-\mathrm{Et})$ and $\mathrm{BuOH}(\mathrm{OP}-\mathrm{Bu})$.

\section{Chemicals}

Cell Counting Kit-8 including 2-(2-methoxy4-nitrophenyl)-3-(4-nitrophenyl)-5-(2,4disulfophhenyl)-2H-tetrazolium,monosodium salt (WST-8) was from Dojindo Co., Kumamoto, Japan. RPMI 1640 medium was from Nissui Pharmaceutical Co., Tokyo, Japan. Fetal bovine serum (FBS) was from Life Technologies Co., Carlsbad, CA, USA. Penicillin- streptomycin was from Roche Diagnostics K. K., Tokyo, Japan. Trypan blue solution was from Nacalai Tesque, Inc., Kyoto, Japan. Aphidicolin were purchased from Wako Pure Chemical Industries, Osaka, Japan.

\section{Cells}

Human promonocytic leukemia U937 cells, acute $\mathrm{T}$ cell leukemia Jurkat cells and breast cancer MCF-7 cells were obtained from Institute of Development, Ageing and Cancer, Tohoku University. Human bile duct cancer TYBDC-1 cells and human endometrial adenocarcinoma (HEC-1) cells were obtained from the JCRB Cell Bank. Human breast cancer MDA-MB-231(MDA) cells and prosate cancer LNCap cells were purchased from DS Pharma Biomedical Co. (Tokyo, Japan). Normal human dermal fibroblasts (NHDF) cells were purchased from Takara bio Co. (Tokyo, Japan). U937, Jurkat and LNCap were maintained in RPMI 1640 medium. MCF-7 and HEC-1 were grown EMEM. MDA cells were grown L-15 medium, and TYBDC-1 cells were maintained DMEM and Ham's F12 medium. All cell cultures were supplemented with heat-inactivated fetal bovine serum $10 \%(\mathrm{v} / \mathrm{v})$, penicillin (100 $\mathrm{IU} / \mathrm{ml}$ ), and streptomycin (100 $\square \mathrm{g} / \mathrm{ml}$ ) at 37 ${ }^{\circ} \mathrm{C}$ in an atmosphere of $95 \%$ air/ $5 \% \mathrm{CO}_{2}$.

\section{Cell viability and cytotoxic assay}

Cells $\left(2 \times 10^{4}\right.$, in $90 \square 1$ solution) were cultured in 96-well flat-bottom plate and treated with various concentrations of each samples for 48 $\mathrm{h}$ at $37{ }^{\circ} \mathrm{C}$ in an atmosphere of $95 \%$ air and $5 \% \mathrm{CO}_{2}$. Cytotoxic activity and cell viability and cell growth were evaluated by trypan blue $(0.5 \%(\mathrm{w} / \mathrm{v}))$ exclusion and by the WST-8 assay (10 $\square 1)$, respectively. The reduction in proportion of living cells was assayed by measurement of absorbance at $450 \mathrm{~nm}$ (reference, $600 \mathrm{~nm}$ ) using the GloMax Multi Detection System.

\section{Nuclear Staining with Hoechst 33258}

U937 cells $\left(1 \times 10^{6}\right.$ cells/dish $)$ were plated in $6-\mathrm{cm}$ dish and then treated with or without OP-He. After $48 \mathrm{~h}$ incubation, the harvested cells were washed with PBS, and fixed with $1 \%$ glutaraldehyde for $30 \mathrm{~min}$. After washing with PBS, the cells were stained with Hoechst 33258 for $10 \mathrm{~min}$. The cells were washed with PBS and their nuclear morphology was observed by fluorescent microscopy (Eclipse E600, Nikon, Tokyo, Japan).

\section{DNA Fragmentation Analysis}

U937 cells $\left(1 \times 10^{6}\right.$ cells/dish $)$ were plated in 6-cm dish and then treated with or without $\mathrm{OP}-\mathrm{He}$ and OP-Bu. After the treatments, the cells were washed with ice-cold PBS and resuspended in lysis buffer $(50 \mathrm{mM}$ Tris- $\mathrm{HCl}$, pH8.0, $10 \mathrm{mM}$ EDTA, and 0.5\% SDS) with $0.2 \mathrm{mg} / \mathrm{ml} \mathrm{RNase} A$ for $30 \mathrm{~min}$ at $50{ }^{\circ} \mathrm{C}$. 
Proteinase $\mathrm{K}$ was added and cells were incubated overnight. The DNA was separated using a 2\% agarose gel and visualized under UV illumination after staining with ethidium bromide.

\section{Flow Cytometry Analysis of Apoptotic Cells}

Cell cycle analysis to detect the sub-G1 phase cells was performed using a cell cycle phase determination kit (Cayman Chemical, Ann Arbor, MI) according to the manufacturer's instructions. U937 cells $\left(1 \times 10^{6}\right.$ cells/dish) were plated in 6-cm dish, and treated with or without OP-He. After treatment with $\mathrm{OP}-\mathrm{He}$ for $48 \mathrm{~h}$, the cells were centrifuged and washed twice with assay buffer. And then, the cells were fixed with fixative and suspended with staining solution containing propidium iodide (PI) and RNase A. The sub-G1 peak was measured and analyzed in the FL2 channel of a FACSCalibur flow cytometer (Becton Dickinson, San Jose, CA) with 488 $\mathrm{nm}$ excitation laser. The cells $\left(2 \times 10^{4}\right.$ cells $)$ were counted for each sample.

\section{Analysis of FITC-labeled annexin V binding and propidium iodide incorporation}

Cell apoptosis was detected using Annexin VFITC Apoptosis detection kit I (BD Biosciences, San Diego, CA, USA) according to the manufacturer's instructions. U937 cells $\left(1 \times 10^{6}\right.$ cells/dish) were plated in $6-\mathrm{cm}$ dish, and treated with or without OP-He. After treatment with OP-He for 12, 24 and $48 \mathrm{~h}$, the cells were centrifuged and washed twice with cold PBS. The cells were re-suspended in binding buffer and then incubated with Annexin V-FITC and PI for $15 \mathrm{~min}$ at room temperature in the dark. Samples werethen analyzed by FACSCalibur flow cytometer (Becton Dickinson, San Jose, CA) The cells $\left(2 \times 10^{4}\right.$ cells) were counted for each sample.

\section{Statistical analysis}

The results of experiments are presented as mean \pm standard error (SE). Differences in means were evaluated by two-tailed Student's $t$-test with $P$ values $<0.05$ considered to be statistically significant.

\section{Results and Discussion}

\section{Culture of Ophiocordyceps pulvinata and preparation of secondary metabolites}

C. militaris and other species were initially cultured using the experimental conditions reported by Kobayashi (Kobayashi, 1941). However, reproducibility was poor because all of the fruiting bodies that developed were synnemata, and no ascocarps formed. In addition, the methods reported by Harada et $a l$. and Chen et al. employ parasitic insects (Kepler et al., 2012; Chen et al., 2002; Sato et al., 2002) and are associated with safety concerns for use in the medical industry.

Therefore, we successfully developed a stable Chu-Soh culture system that has a high level of safety. It also permits the efficient formation of sexual fruiting bodies on the culture medium that are comparable with those that develop in the wild, and allow the production of different lots with the same efficacy.

Using this artificial liquid medium, we were able to culture samples in large quantities (Yahagi et al., 2004). Figure 1B shows the fruiting bodies developed from $O$. pulvinata on agar. The metabolite-containing media obtained from this culture system were filtered through a membrane filter and freezedried for use in subsequent experiments.

The freeze-dried secondary metabolite filtrates were approximately $0.03-0.05 \% \mathrm{w} / \mathrm{v}$ for $O$. pulvinata. 
Anti-proliferative activity of $O$. pulvinata secondary metabolites on human cancer cells

The anti-proliferative activity of $O$. pulvinata secondary metabolites (OP-FD) was tested with human leukemia cells (U937 and Jurkat), human breast cancer cells (MCF7 and MDAMB-231), human prostate cancer cells (LNCap), human bile duct cancer cells (TYBDC-1), and. human endometrial adenocarcinoma cells (HEC-1). As shown in Figure 2, OP-FD potently inhibited cell proliferation in a concentration-dependent manner in leukemia cells (U937 and Jurkat) and breast cancer cells (MCF7 and MDAMB-231). Activity levels observed with other cancer cells were noticeably lower. The $\mathrm{IC}_{50}$ value of OP-FD on cell proliferation was 350 $\mu \mathrm{g} / \mathrm{mL}$ in the leukemia cells and $640 \mu \mathrm{g} / \mathrm{mL}$ in the breast cancer cells. The $\mathrm{IC}_{50}$ value in normal human skin fibroblasts was $\geq 2500$ $\mu \mathrm{g} / \mathrm{mL}$.

To identify active components, OP-FD was subjected to heating and then administered to leukemia cells. The antitumor activity of OPFD was not affected by heating. Next, a methanol extract of OP-FD was subjected to solvent partitioning using hexane, chloroform, ethyl acetate, and 1-butanol. The soluble fraction of each solvent was administered to the leukemia and breast cancer cells. As shown in Figure 3, OP- $\mathrm{He}$ and $\mathrm{OP}-\mathrm{CH}$ showed potent and concentration-dependent antitumor activity on all cell types. For U937 cells, the $\mathrm{IC}_{50}$ values of $\mathrm{OP}-\mathrm{He}$ and $\mathrm{OP}-\mathrm{CH}$ were $\leq 4 \mu \mathrm{g} / \mathrm{mL}$ and $4 \mu \mathrm{g} / \mathrm{mL}$, respectively, which were substantially lower than those of OP-FD.

\section{Confirmation of apoptosis induction by OP-He}

To determine whether the inhibition of cell proliferation by OP-He was due to apoptosis, morphological changes to the nucleus and DNA fragmentation were investigated. Nuclear morphology was observed in cells stained with Hoechst 33258 using a fluorescence microscope. DNA fragmentation was detected using agarose gel electrophoresis of cells treated with RNase and proteinase $\mathrm{K}$. OP-He caused chromatin aggregation (Fig.4A) and DNA fragmentation (Fig.4B) that was characteristic of apoptosis in leukemia cells. OP-He induced a timedependent increase in the binding of annexin $\mathrm{V}$ to phosphatidylserine (PS) that migrated toward the outer layer of the cell membrane (Fig.4C). The presence of PS is another biochemical characteristic of apoptosis. Furthermore, a FACS analysis of the sub- $\mathrm{G}_{1-}$ phase population of propidium iodide-stained cells revealed a marked increase in the sub- $\mathrm{G}_{1}$ population of OP-He-treated cells (Fig.4D). These results suggest that OP-He inhibits the proliferation of leukemia cells by inducing apoptosis.

\section{Analysis of apoptotic mechanisms induced by OP-He}

To determine the mechanism underlying the apoptosis-inducing effect of OP-He on U937 cells, caspase activation was assessed. Treatment with OP-He activated caspase-9 and -3 (Fig.5A). Mitochondria are closely involved in apoptosis induced by various stimuli. Therefore, we measured the mitochondrial membrane potential (MMP) using JC-1. Cells treated with OP-He showed a time-dependent decrease in MMP (Fig.5B).

C. militaris is an extensively studied species that contains an abundance of physiologicall active substances such as cordycepin, $\beta$ glucans, and ergosterol (Chen et al., 2013; Jeong et al., 2012; Jeong et al., 2013; Kobori et al., 2007; Nallathamby et al., 2015; Park et al., 2009; Yoshikawa et al., 2004). Cordycepin is an adenosine derivative that 
potentially inhibits cancer cell proliferation through stimulation of the adenosine A 3 receptor (Tian et al., 2015; Yoshikawa et al., 2011). Cordycepin also activates AMPactivated protein kinase (AMPK). AMPK plays an important role in intracellular signaling and can suppress cancer cell proliferation (Wu et al., 2014; Zhang et al., 2014). Moreover, it has been reported that different Cordyceps species have varying activities, as exemplified by FTY720, an immunosuppressive compound found in Isaria cicadae Miquel that parasitizes Meimuna opalifera (Bhatti et al., 2013). We conducted antitumor screening in human cancer cells and found that low concentrations of secondary metabolites of $O$. pulvinata $(\mathrm{OP}-$ FD) effectively and specifically inhibited the proliferation of leukemia and breast cancer cells but not of normal (NHDF) cells. These findings indicate that susceptibility to OP-FD widely varies among different cancer cells.
Acute and chronic toxicity experiments in mice showed no major differences in body weight gain or organ abnormalities between the control and test groups. Based on these findings, unknown components in the metabolic fluid of $O$. pulvinata may serve as new lead compounds for the development of anticancer drugs with minimal side effects. To characterize the active substances in OP-FD, heated OP-FD was administered to leukemia cells. The heated OP-FD preparation was as effective as the unheated preparation in terms of antitumor activity. Next, the methanol extract of OP-FD was subjected to solvent partitioning with hexane, chloroform, ethyl acetate, and 1-butanol and then tested for antitumor activity. The hexane and chloroform fractions had a strong antitumor effect. These results suggest that the active substance is a highly hydrophobic, lowmolecular weight compound.

Fig.1 Artificial culture and natural products of Ophiocordyceps pulvinata.

(A) Specimens of Ophiocordyceps pulvinata in natural field.

Arrow indicates stromata caused to wrap around the neck of ant.

(B) Fruiting bodies produced by Ophiocordyceps pulvinata in culture medium.
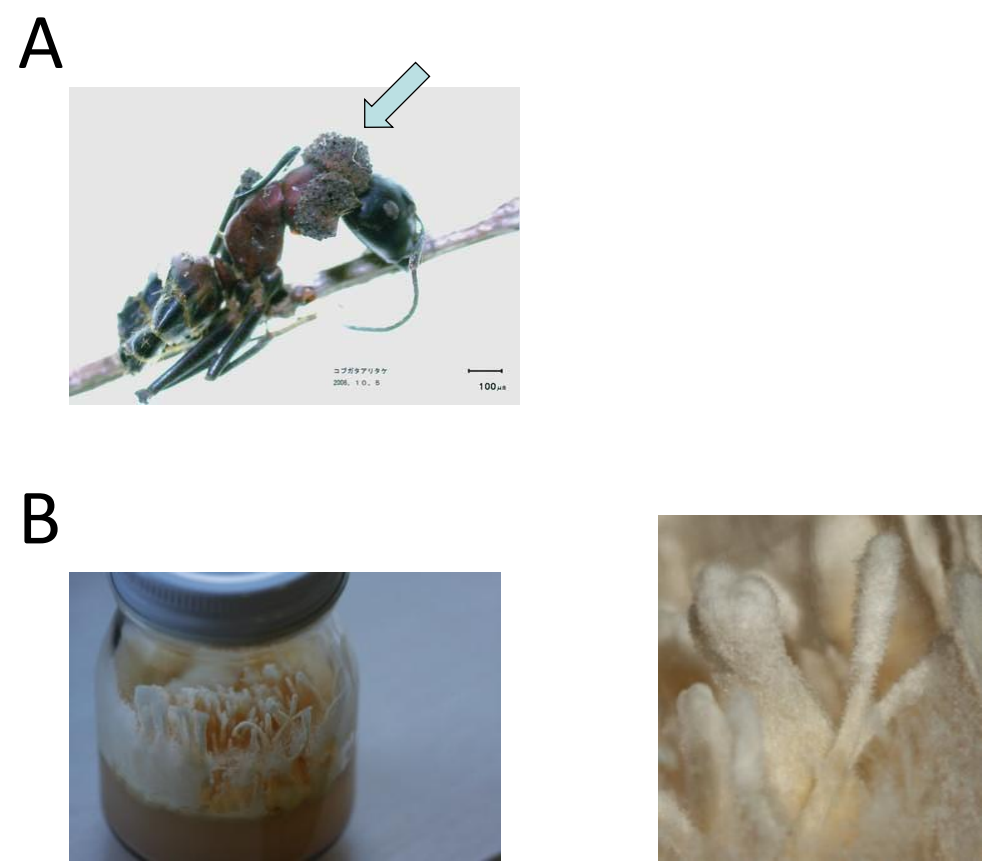
Fig.2 Inhibitory effect of secondary metabolites of Ophiocordyceps pulvinata (OP-FD) on the Growth of human tumor cells Cells were treated with OP-FD [2500-80 $\square \mathrm{g} / \mathrm{m}]$ for 48h. Then cell viability was determined by WST-8 assay and trypan blue dye exclusion assay.

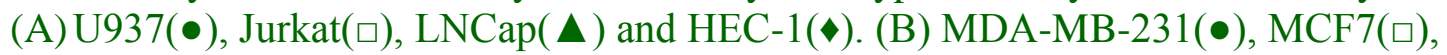
TYBDC-1 $(\boldsymbol{\Delta})$ and $\operatorname{NHDF}(\diamond)$.
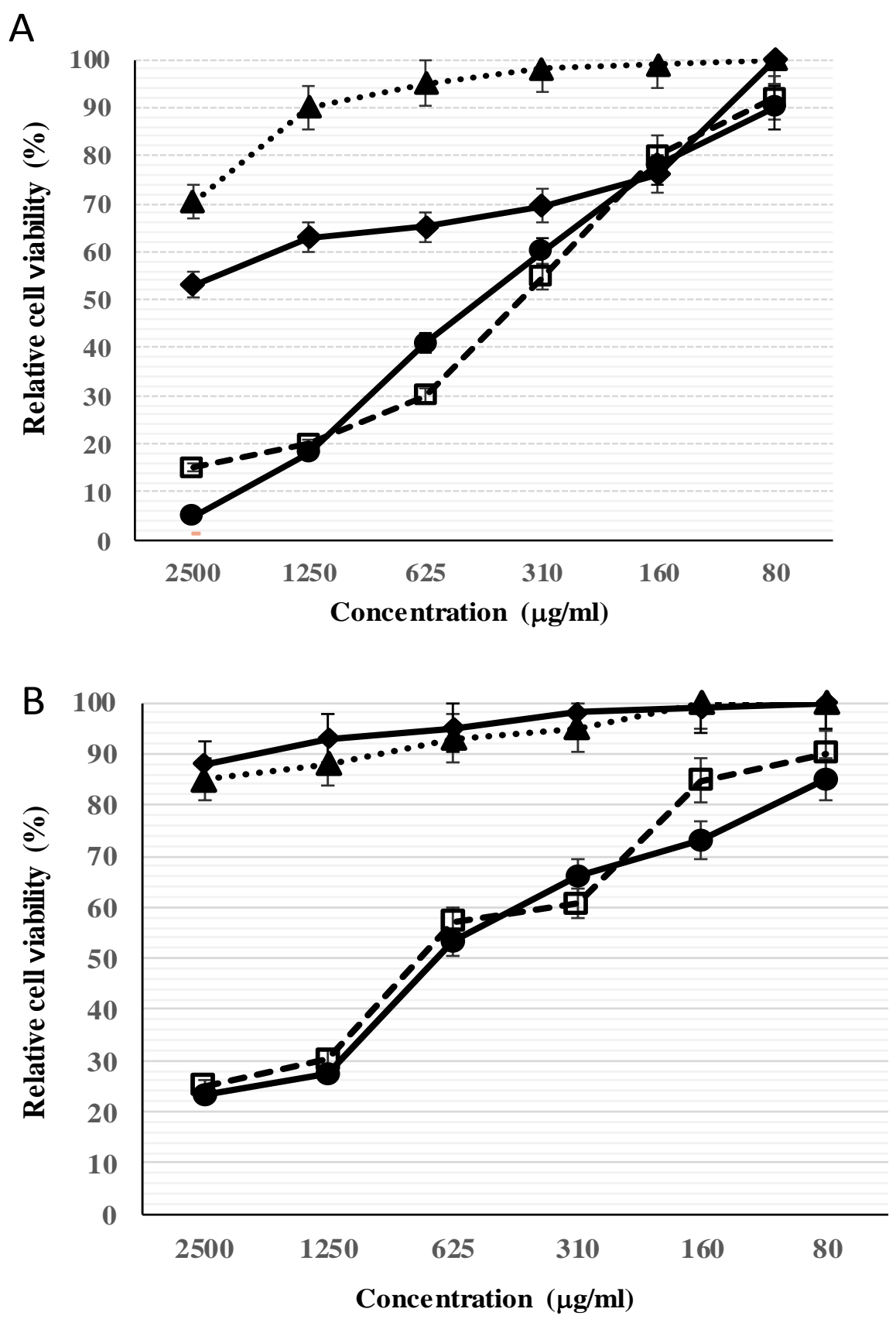
Fig.3 Anti-cancer effect of organic solvent extracted fraction of OP-FD on the Growth of human tumor cells U937 cells (A) and MDA-MB-231 cells (B) were treated with $\mathrm{OP}-\mathrm{He}(\bullet), \mathrm{OP}-\mathrm{CH}(\boldsymbol{\bullet})$, $\mathrm{OP}-\mathrm{Et}(\boldsymbol{\Delta}), \mathrm{OP}-\mathrm{Bu}(\bullet)$ and $\mathrm{OP}-\mathrm{H} 2 \mathrm{O}(\square)[125-4 \square \mathrm{g} / \mathrm{ml}$ for $48 \mathrm{~h}$. Then cell viability was determined by WST-8 assay and trypan blue dye exclusion assay

A

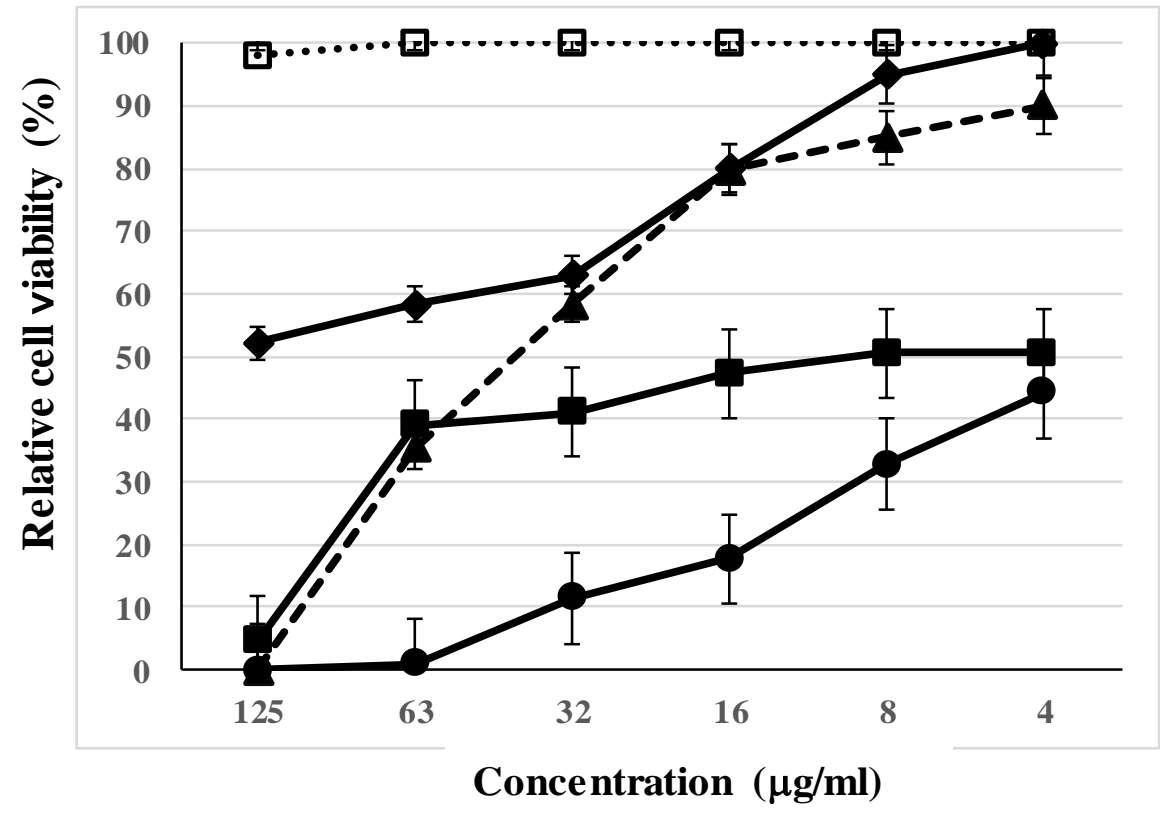

B

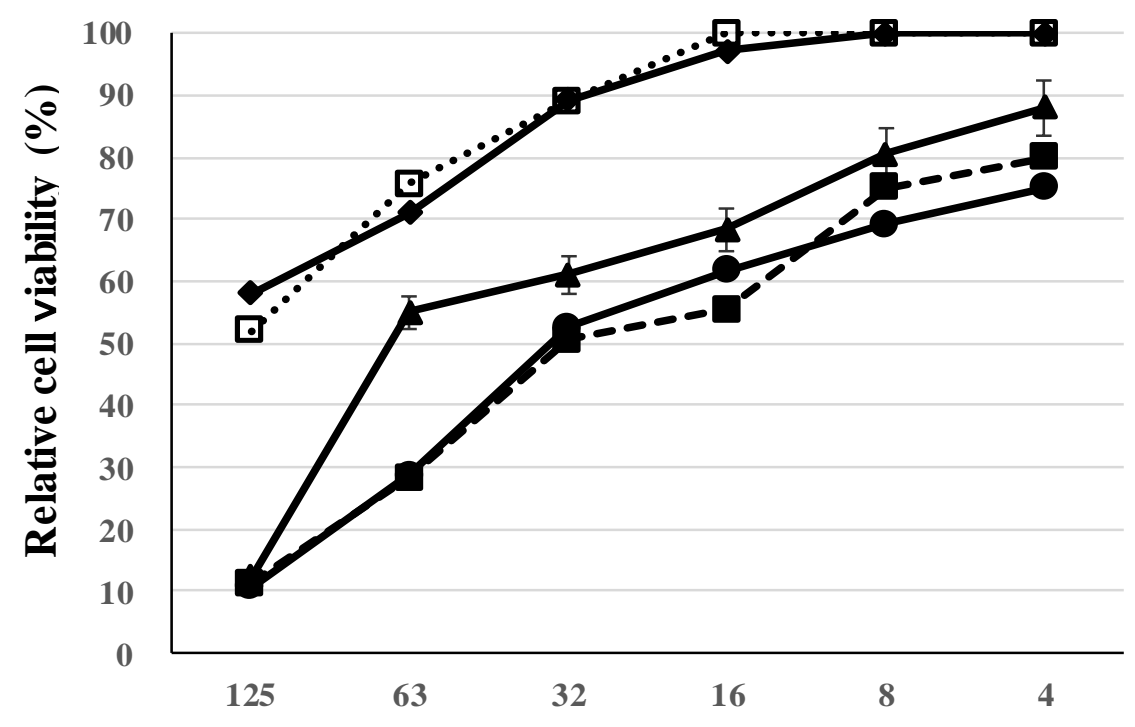

Concentration $(\mu \mathrm{g} / \mathrm{ml})$ 
Fig.4 Effect of organic solvent extracted fraction of OP-FD on apotosis induction.

(A) Induction of chromatin condensation by OP-He. U937 cells were treated with OP-He for 48h and stained with Hoechst 33258. The nuclear morphology was observed fluorescent microscopy (magnification x400) (B) Induction of DNA fragmentation by OP-He. U937 cells were treated with OP$\mathrm{He}$ at various concentrations for 48h. DNA fragmentation was analyzed by agarose gel electrophoresis. (C) Analysis of FITC-labeled annexin V binding and propidium iodide incorporation. U937 cells were treated with $16 \mu \mathrm{g} / \mathrm{ml} \mathrm{OP}-\mathrm{He}$ for $48 \mathrm{~h}$, and analyzed by flow cytometry after staining with FITC-annexin V and PI. The data shown are representative of three independent experiments with similar results. (D) Increase of the sub-G1 phase cells by OP-He. U937 cells were treated with $16 \mu \mathrm{g} / \mathrm{ml} \mathrm{OP-He}$ for $48 \mathrm{~h}$, and analyzed by flow cytometry after staining with PI. The data shown are representative of three independent experiments with similar results.

A

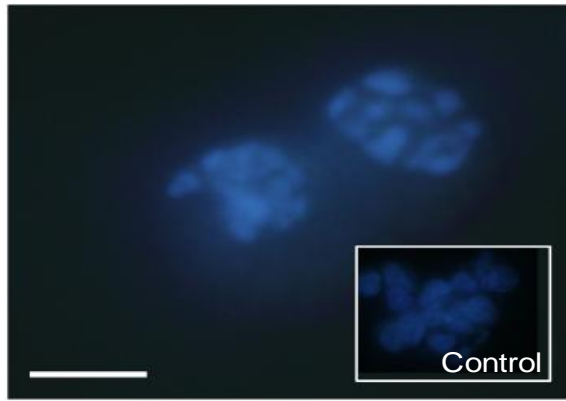

C

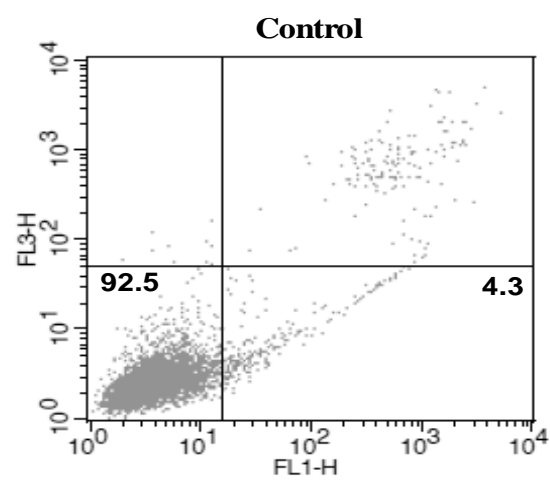

D

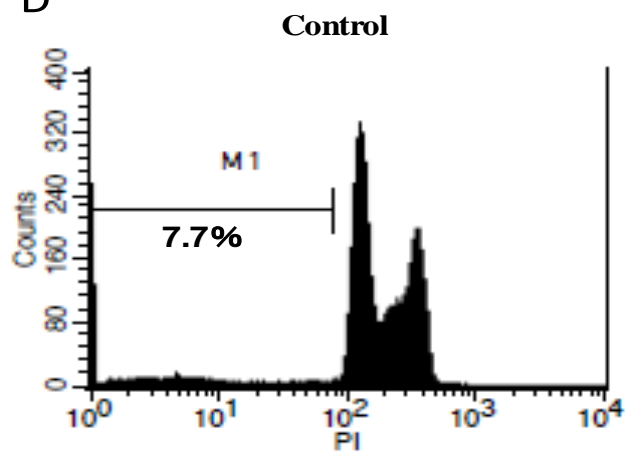

B
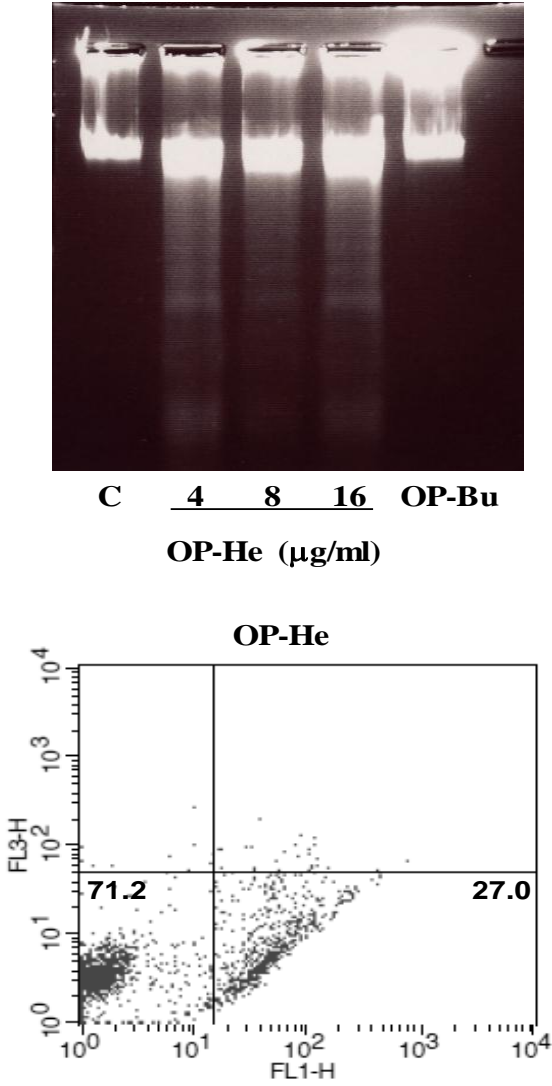

OP-He

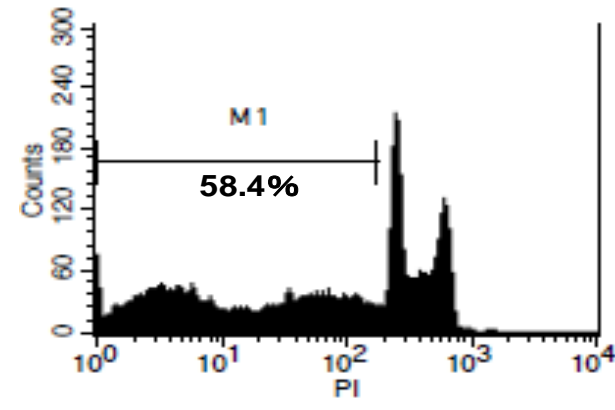


Fig.5 OP-He induced apoptosis through a caspase-mediated pathway in U937 cells. (A) Involvement of the caspase cascade in OP-He-induced apoptosis. U937 cells were treated with $16 \mu \mathrm{g} / \mathrm{ml}$ OP-He for the times indicated. Cells were lysed and treated with substrate of caspase-3,-9 and the activity were measured. Error bars: SE from three different cell preparations assayed individually. (B) Effect of OP-He on the loss of $\Delta \Psi \mathrm{m}$. U937 cells were treated with $16 \square \mathrm{g} / \mathrm{ml} \mathrm{OP}-\mathrm{He}$ for the times indicated and analyzed by flow cytometry after staining with JC-1.

\section{A}
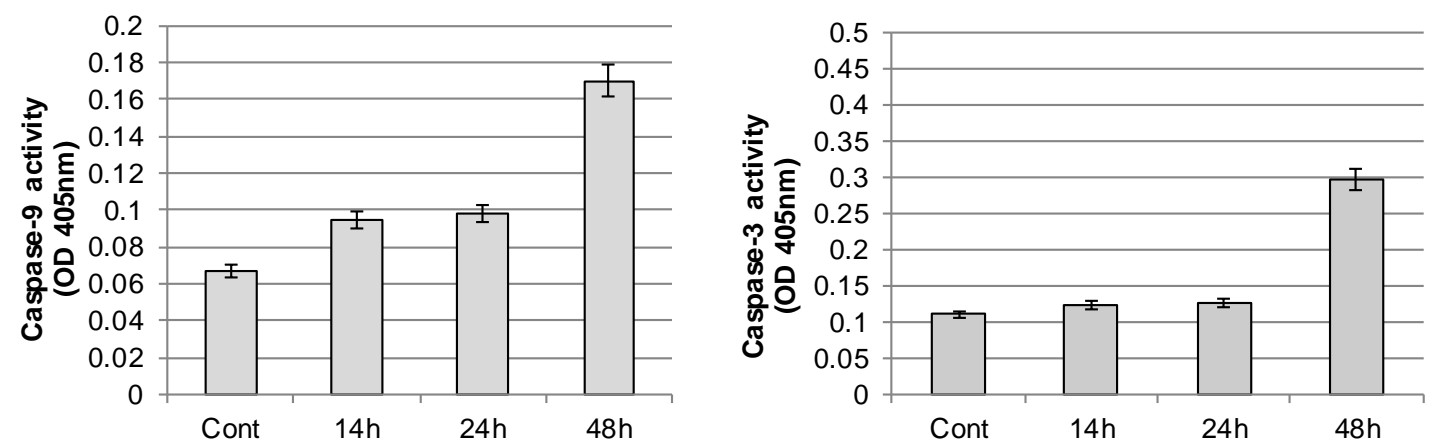

B
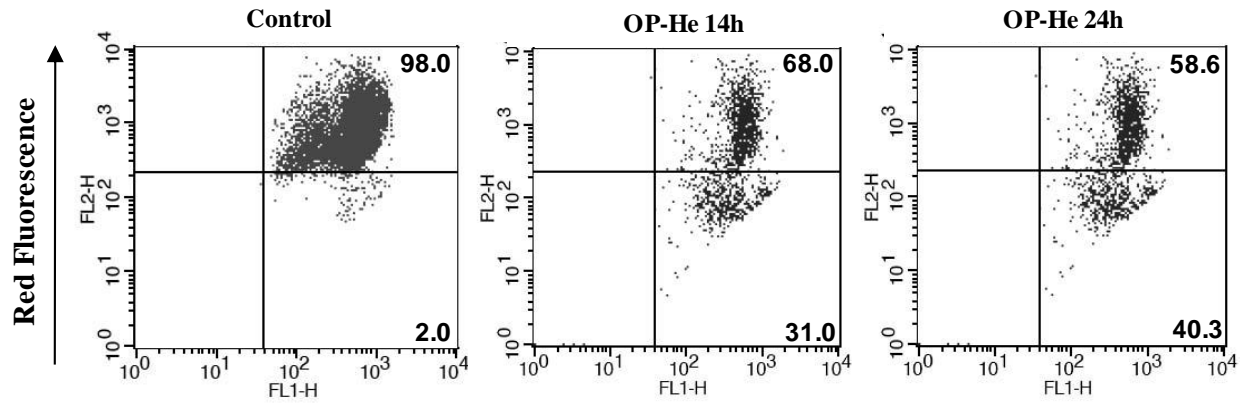

Green Fluorescence

In vivo mechanisms induce cell death in unnecessary or harmful cells. Apoptosis plays an important role in not only the elimination of unnecessary cells during development and regeneration processes but also the elimination of cancer and virus-infected cells. When the cellular switch for apoptosis is turned on, proteases called caspases in the cell are activated. Activated caspases break down multiple protein molecules essential for cell survival and thereby induce cell death (Galluzzi et al., 2016). An apoptotic cell is broken into several small fragments (apoptotic bodies) with characteristic morphological features such as chromatin condensation. However, the cell membrane does not rupture, and cell contents never leave the cell. A major feature of apoptosis is the cleavage of chromosomal DNA into nucleosome units. A caspase-activated DNAdegrading enzyme has been reported to be involved in this DNA cleavage process (Hamacher-Brady et al., 2015; Larsen et al., 2016). Dead cells are processed by phagocytes such as macrophages (Mitra et al. 2015). Macrophages recognize a lipid called PS found only on the surface of apoptotic cells. Furthermore, autoimmune diseases can inhibit the ability of macrophages to process apoptotic cells (Cummings et al., 2016). In 
the present study, chromatin condensation, nuclear fragmentation, and increased annexin $\mathrm{V}$ binding were observed in leukemia cells treated with OP-He, indicating the induction of apoptosis. Three major apoptosis signaling pathways are known: death receptor-mediated pathway, mitochondrial pathway, and endoplasmic reticulum stress pathway. Treatment with OP-He reduced the MMP and activated caspase-9 and -3 . This result suggests that OP-He induces apoptosis through the caspase-dependent mitochondrial pathway. Because OP-He showed antitumor effects on breast cancer and leukemia cells, it is likely to reduce the side effects in chemotherapy-treated patients with breast cancer and the risk of developing leukemia in patients receiving radiation therapy.

Cordyceps fungi, including $O$. pulvinata, contain various substances. Thus, these fungi may produce not only antitumor effects but also immunostimulatory effects via additive and synergistic interactions. Determining the physiologically active components in these species is expected to produce new lead compounds for anticancer drugs, apart from cordycepin and ergosterol peroxide.

\section{References}

Bok, J.W., Lermer, L., Chilton, J., Klingeman, H.G., Towers, G.H., 1999. Antitumor sterols from the mycelia of Cordyceps sinensis. Phytochemistry, 51, 891-898.

Bhatti, M.T., Freedman, S.M., Mahmoud, T.H., 2013. Fingolimod Therapy and Mocular Hemorrhage. J. neuroophthalmol. 33(4), 370-372.

Chen, R., Ichida, M., 2002. Infection of the silkworm, Bombyx mori, with Cordyceps Militaris. J. Inect Biotech. Sericol. 71, 6163.

Chen, Y.H., Wang, J.Y., Pan, B.S., Mu, Y.F., Lai, M.S., So, E.C., Wong, T.S., Huang, B.M., 2013. Cordycepin enhances cisplatin apoptotic effect through
caspase/MAPK pathways in human head and neck tumor cells. Onco. Tagets Ther. 25, 983-998.

Cheng, Y.W., Chen, Y.I., Tzeng, C.Y., Chang, C.H., Lee, Y.C., Chen, H.C., Tsai, C.C., Hsu, T.H., Lai, Y.K., Chang, S.L., 2013. Aqueous extracts of Cordyceps militaris (Ascomycetes) lower the levels of plasma glucose by activating the cholinergic nerve in streptozotocin-induced diabetic rats. Int J Med Mushrooms, 15, 277-286.

Cummings, R.J., Barbet G., Bongers, G., Hartmann, B.M., Gettler, K., Muniz, L., Furtado, G.C., Cho, J., Lira, S.A., Blander, J.M., 2016. Different tissue phagocytes sample apoptotic cells to direct distinct homeostasis programs. Nature, 539(7630), 565-569

Galluzzi, L., López-Soto, A., Kumar, S., Kroemer, G., 2016. Caspases Connect Cell-Death Signaling to Organismal Homeostasis. Immunity, 44(2), 221-231.

Hamacher-Brady, A., Brady, N.R., 2015. Bax/Bak-dependent, Drp1-independent Targeting of X-linked Inhibitor of Apoptosis Protein (XIAP) into Inner Mitochondrial Compartments Counteracts Smac/DIABLO-dependent Effector Caspase Activation. J. Biol. Chem., 290(36), 22005-22018.

Larsen, B.D., Sørensen C.S., 2016. The caspase-activated DNase: apoptosis and beyond. FEBS J., doi: 10.1111/febs.13970.

Jeong, J.W., Jin, C.Y., Park, C., Han, M.H., Kim, G.Y., Moon, S.K., Kim, C.G., Jeong, Y.K., Kim, W.J., Lee, J.D., Choi, Y.H., 2012. Inhibition of migration and invasion of LNCaP human prostate carcinoma cells by cordycepin through inactivation of Akt. Int. J.Oncol. 40, 1697-1704.

Jeong, M.H., Lee, C.M., Lee, S.W., Seo, S.Y., Kang, B.W., Jeong, Y.K., Choi, Y.J., Yang, K.M., Jo, W.S., 2013. Cordycepinenriched Cordyceps militaris induces immunomodulation and tumor growth delay in mouse-derived breast cancer. Oncol. Rep. 30, 1996-2002. 
Kepler, R.M., Sung, G.H., Harada, Y., Tanaka, K., Tanaka, E., Hosoya, T., Bischoff, J.F., Spatafora, J.W., 2012. Host jumping onto close relatives and across kingdoms by Tyrannicordyceps (Clavicipitaceae) gen. nov. and Ustilaginoidea_(Clavicipitaceae). Am. $J$. Bot., 99(3), 552-561.

Kobayashi, Y., 1941. The genus Cordyceps and its allies. Science Report of The Tokyo Bunrika Daigaku Section B, 5(84), 53260.

Kobori, M., Yoshida, M., Ohnishi-Kameyama, M., Shinmoto, H., 2007. Ergosuterool peroxidefrom an edible mushroom suppresses inflammatory responses in RAW264.7 macrophages and growth of HT29 colon adenocarcinoma cells. Br. J. Pharmacol., 150, 209-219.

Kodama, E.N., McCaffrey, R.P., Yusa, K., 2000. Mitsuya, H. Antileukemic activity and mechanism of action of cordycepin against terminal deoxynucleotidyl transferase-positive (TdT +$)$ leukemic cells. Biochem Pharmacol. 59, 273-281.

Lee, H.H., Park, C., Jeong, J.W., Kim, M.J., Seo, M.J., Kang, B.W., Park, J.U., Kim, G.Y., Choi, B.T., Choi, Y.H., Jeong, Y.K, 2013. Apoptosis induction of human prostate carcinoma cells by cordycepin through reactive oxygen species-mediated mitochondrial death pathway. $J$. Oncology, 42, 1036-1044.

Lee, W.S., Li, H.H., Sheng, Y., Jian D.J., Shao, Y.R., 2016. Cordycepin induces apoptosis in human liver cancer HepG2 cells through extrinsic and intrinsic signaling pathway. Oncol.Lett., 12, 995-1000.

Ma, L., Zhang S., Du, M., 2015, Cordycepin from Cordyceps militaris prevents hyperglycemia in alloxan-induced diabetic mice. Nutr. Res., 35(5), 431-439.

Mitra, S., Wewers, M.D., Sarkar A., 2015. Mononuclear Phagocyte-Derived Microparticulate Caspase-1 Induces Pulmonary Vascular Endothelial Cell Injury. PLoS One, 10(12), e0145607. doi: 10.1371/journal.pone.0145607

Nakamura, K., Yamaguchi, Y., Kagota, S.,
Kwon, Y.M., Shinozuka, K., Kunitomo, M., 1999. Inhibitory Effect of Cordyceps sinensis on Spontaneous Liver Metastasis of Lewis Lung carcinoma and B16 Melanoma Cells in Syngenic Mice. Jpn. J. Pharmacol. 79, 335-341.

Nallathamby, N., Guan-S, L., Vidyadaran, S., Abd, M.S.N., Raman, J., Sabaratnam, V., 2015, Ergosterol of Cordyceps militaris Attenuates LPS Induced Inflammation in BV2 Microglia Cells. Nat. Prod. Commun., 10(6), 885-886.

Ogawa, Y., Yahagi, N., Yahagi, R., Kobayashi, H., 2014. Specific antiproliferative activity Against human cancer cells with metabolites from several species related to the genus Cordyceps. Int. J. Curr. Microbiol. App.Sci, 3(5), 607-617.

Oh, J.Y., Baek, Y.M., Kim, S.W., Hwang, H. J., Hwang, H. S., Lee, S. H., Yun, J. W., 2008. Apoptosis of human hepatocarcinoma (HepG2) and neuroblastoma $(\mathrm{SKN}-\mathrm{SH})$ cells induced by polysaccharides-peptide complex produced by submerged mycelial culture of an entomopathogenic fungus Cordyceps sphecocephala. J. Microbiol. Biotechnol., 18, 512-519.

Paterson, R.R.M., 2008. Cordyceps - A traditional Chinese medicine and another fungal therapeutic biofactory. Phytochemistry, 69, 1469-1495.

Sagara, Y., Freedman, R.A., Vaz-Luis, I., Mallory, M.A., Wong, S.M., Aydogan, F., DeSantis, S., Barry, W.T., Golshan, M., 2016. Patient Prognostic Score and Associations With Survival Improvement Offered by Radiotherapy After BreastConserving Surgery for Ductal Carcinoma In Situ: A Population-Based Longitudinal Cohort Study. J. Clin Oncol., 34(11), 1190-6.

Saito, M., Mori, A., Irie, T., Tanaka, M., Morioka, M., 2009. Therapy-related acute myeloid leukemia with 11q23 abnormality due to paclitaxel coexisting with bone marrow metastasis of breast cancer. The Jap. Soc.Hematology, 50(3), 192-196. 
Sato, H., Shimizu, M., 2002. Storomata production for Cordyceps militaris (Clavicipitales: Clavicipitaceae) by infection of hyphal bodies to alternative host insects. Appl. Entomol. Zool, 37, 8592.

Shao, L.W., Huang, L.H., Yan, S., Jin, J.D., Ren, S.Y., 2016. Cordycepin induces apoptosis in human liver cancer HepG2 cells through extrinsic and intrinsic signaling pathways. Oncol. Lett., 12(2), 995-1000.

Takano, F., Kikuchi, Y., Fushiya, S., Hojo, H., Nozoe, S., Yahagi, N., Kondo, Y., 1996.

The culture fluid of Isaira japonica yasuda augments anti-sheep red blood cell antibody response in mice. Biol. Pharm. Bull. 19, 641-643.

Tian, X., Li, Y., Shen, Y., Li, Q., Wang, Q., Feng, L., 2015. Apoptosis and inhibition of proliferation of cancer cells induced by cordycepin. Oncol. Lett., 10(2), 595-599.

Wu, C., Guo, Y, Su, Y., Zhang, X., Luan, H., Zhang, X., Zhu, H., He, H., Wang, X., Sun, G., Sun, X., Guo, P., Zhu, P., 2014. Cordycepin activates AMP-activated protein kinase (AMPK) via interaction with the $\gamma 1$ subunit. J. Cell Mol. Med., 18(2), 293-304.

Yahagi, N., Komatsu, M., Hiramatsu, M., SHI, H., Yahagi, R., Kobayashi, H., Kamada, H., Takano, F., Fushiya, S., 1999. Radical Scavenging Activities of Condensed Culture Medium of Isaria japonica Yasuda and Hot water Extract of Fomes fomentarius (L.:Fr) Kicrx. Nat. Med. 53, 319-323.

Yahagi, N., Yahagi, R., Takano, F., Fushiya, S., Tanaka, T., Tanaka, K., Ohta, T., 2004. Growth of ascocarps from cultured Cordyceps militaris (L.:Fr.) Fr. and Cordyceps formicarum Kobayasi in an agar medium. Kingakukai kaiho, 45, 1519.

Yoshikawa, N., Nakamura, K., Yamaguchi, Y., Kagota, S., Shinozuka, K., Kunimoto, M., 2004. Antitumor activity of cordycepin in mice. Clin. Exp. Pharmacol. Physiol. Suppl 2, S51-3.

Yoshikawa, N., Nishiuchi, A., Kubo, E., Yamaguchi, Y., Kunitomo, M., Kagota, S., Shinozuka, K., Nakamura, K., 2011. Cordyceps sinensis acts as an Adenosine $\mathrm{A}_{3}$ receptor agonist on mouse melanoma and lung carcinoma cells, and human fibrosarcoma and colon carcinoma cells. Pharmacol. Pharmacy, 2, 266-270.

Yu, S.H., Dubey, N.K., Li, W.S., Liu, M.C., Chiang, H.S., Leu, S..J, Shieh, Y.H., Tsai,.FC., Deng, WP., 2016. Cordyceps militaris Treatment Preserves Renal Function in Type 2 Diabetic Nephropathy Mice. PLoSOne,11(11): e0166342. doi:10.1371/journal.pone. 0166342.

Zhang, J.L., Xu, Y., Shen, J., 2014. Cordycepin inhibits lipopolysaccharide (LPS)-induced tumor necrosis factor (TNF)- $\alpha$ production via activating amp-activated protein kinase (AMPK) signaling. Int. J. Mol. Sci., 15(7), 12119-12134.

\section{How to cite this article:}

Yukiko Ogawa, Osamu Morinaga, Nobuo Yahagi, Remiko Yahagi and Hidemitsu Kobayashi. 2017. Ophiocordyceps pulvinata Induces Caspase-Dependent Apoptosis through Mitochondrial Impairment in Human Leukemia Cells. Int.J.Curr.Microbiol.App.Sci. 6(1): 579-591. doi: http://dx.doi.org/10.20546/ijcmas.2017.601.071 